\title{
TESTS OF STELLAR RADIOMETERS AND MEASURE- MENTS OF THE ENERGY DISTRIBUTION IN THE SPECTRA OF 16 STARS
}

\author{
By W. W. Coblentz
}

ABSTRACT

In this paper an account is given ( 1 ) of new tests of stellar radiometers, (2) of new measurements of the total radiation of stars in the region of o hrs. to $12 \mathrm{hrs}$. in right ascension, not previously measured, and $(3)$ of tests of a method of determining the spectral energy distribution of stars by means of transmission screens, which, either singly or in combination, are placed in front of a vacuum thermocouple used as a radiometer.

The results obtained verify previous observations showing that red stars emit three to four times as much total radiation as blue stars of the same visual magnitude.

By means of a series of transmission screens (of yellow and red glass, of water, and of a thick plate of quartz) wide spectral regions were isolated, and the radiation intensities in the spectrum from $0.3 \mu$ to $0.43 \mu, 0.43 \mu$ to $0.6 \mu, 0.6 \mu$ to $I_{.4} \mu, I_{.4} \mu$ to $4 . \mathrm{I} \mu$, and 4. I $\mu$ to Iо $\mu$ were determined. In this manner the energy distribution in the complete spectrum of 16 stars was determined.

The observed spectral radiation components were compared with similar data computed for a black body at various temperatures. In this manner it was found that the temperature which a complete radiator or so-called black body would have to attain in order to emit a spectral energy distribution similar to that observed varies from $3000^{\circ} \mathrm{K}$ for red, class $\mathrm{M}$, stars, to $10000^{\circ} \mathrm{K}$, or even higher, for blue, class $\mathrm{B}$, stars.

The water-cell transmission of binary stars, having companions of low luminosity; is low, indicating that the companion stars emit considerable infra-red radiation.

\section{CONTENTS}

Page

II. Apparatus and methods....

2. Recent tests of thermocouple material................... $7^{28}$

3. Description of vacuum thermocouples used in the present work... $73^{1}$

4. Description of the transmission screens.................. 733

5. The reflecting telescope.......................... 736

III. Measurement of the total radiation from stars................. 737

IV. Measurement of the spectral radiation of 16 stars................ 739

I. Spectral energy data on 16 stars..................... 740

2. The water cell transmission data..................... 743

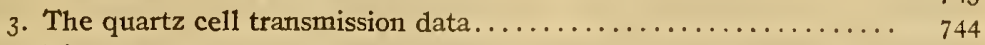

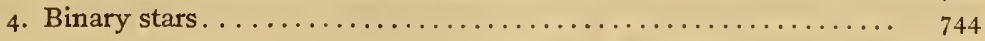

5. Stellar temperatures............................ ${ }_{745}$

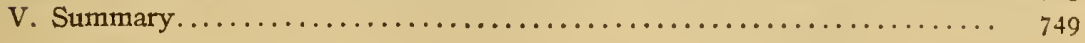




\section{INTRODUCTORY STATEMENT}

During the past summer, through the generosity of the Lowell Observatory, Flagstaff, Ariz. (altitude $7300 \mathrm{ft}$.), the writer was given an opportunity to try out new devices for stellar radiometry and to make new stellar radiation intensity measurements. Not only was an otherwise busy program interrupted but, furthermore, Dr. C. O. Lampland personally operated the telescope, thus insuring speed and efficiency in accomplishing results. It is a pleasure to record here my grateful acknowledgments for the many courtesies extended me by various members of the Lowell Observatory.

The whole experience is an excellent object lesson in what may be accomplished by physicists and astronomers (or, for that matter, by laboratories having a common problem but incomplete apparatus) by combining their forces in trying out new devices, thus saving time and the expense that would be required in building up complete equipment, which in the end may or may not prove satisfactory.

In a previous paper ${ }^{1}$ data were given on a comparison of stellar radiometers and radiometric measurements of IIo stars, using the Crossley reflector of the Lick Observatory at Mount Hamilton, Calif., the altitude being about $4000 \mathrm{ft}$. Quantitative measurements were made on stars down to magnitude 5.3 and qualitative measurements to magnitude 6.7. It was found that red stars emit from 2.5 to 3 times as much total radiation as blue stars of the same visual magnitude.

These observations were verified by an independent method which consisted in measuring the transmission of stellar radiation through a I cm cell of water, having quartz windows. By this means it was shown that of the total radiation emitted blue stars have about 2 times as much visible radiation as yellow stars and about 3 times as much visible radiation as red stars.

The purpose of the present investigation was (I) to verify previous results, (2) to measure the radiation intensities of the bright stars in the region of o hrs. to I 2 hrs. in right ascension, not previously measured, thus completing the survey of the whole sky. (in this latitude), and (3) to determine the feasibility of the method of obtaining the spectral energy distribution of stars by means of transmission screens which either singly or in combination are placed in front of the vacuum thermocouple which was used

1 Coblentz, B. S. Bulletin, 11, p. 6r3; rgr4. 
to measure the thermal radiation intensity. By means of these transmission screens it was possible to obtain for the first time an insight into the radiation intensities in the complete spectrum of a star.

Data on the spectral energy distribution of stars as related to that of a black body are very meager. They are the results practically of the spectrophotometric measurements of Wilsing ${ }^{2}$ and of Nordmann, ${ }^{3}$ and the spectral energy curves determined photographically by Plaskett, ${ }^{4}$ all of which relate to the visible spectrum. From the data obtained on the radiation intensities in the visible spectrum, these experimenters have obtained estimates of stellar temperatures of $3000^{\circ}$ for red stars to $25000^{\circ}$ or even higher for blue stars.

In view of the subject matter to be discussed in this paper, it is relevant to recall that in previous papers it was indicated that, in comparison with the photoelectric cell, the thermocouple is far less sensitive and hence more limited in its application as to the number of stars that can be measured. (Neither instrument can tell us the size or distance of stars). But the thermocouple enables one to obtain information not obtainable by other instruments. Combined with an absorption cell (of water) one can detect the presence of dark companions of binary stars.

This device gives us a new means for studying planetary radiation and temperature conditions. If the surface of a planet becomes warmed by the sun's rays and in turn emits radiation (which will be entirely of long wave lengths), the amount of radiation transmitted through the water cell will be less than when the reflecting surface remains cool. Data of this type were previously obtained on the moon. Applied to the planet Mars, if the polar cap is snow then the transmission of reflected sunlight should be higher than that observed from the dark areas, if the latter are bare ground. On the other hand, if the dark areas contain green vegetation (similar to that of our earth) the temperature rise will be small, the water-cell transmission will be high, and the results may be difficult of interpretation.

\section{APPARATUS AND METHODS}

Under the present caption is given a recapitulation of results obtained in the improvement of stellar radiometers as well as a general description of the instruments used in the present work.

${ }^{2}$ Wilsing, Scheiner, and Münch, Publ. Astrophys. Obs., Potsdam, 24, No. 74 i 1920.

? Nordmann and LeMorvan, C. R., 173, p. 72; 1921.

'Plaskett, Monthly Notices, R. A. S., 80, p. 77r; 1920. 


\section{SUBSIDIARY INVESTIGATIONS IN STELLAR RADIOMETRY}

At various times during the seven years which have elapsed since making the previous stellar radiation measurements attention was given to the improvement of stellar radiometers. A study was made of magnetic shielding, and of some of the problems that will be encountered in using a vacuum galvanometer. ${ }^{5}$

An investigation was made of selective radiometers (photoelectric cells). A new multiple bolometer receiver was described, consisting of two bolometer receivers, one back of the other, which increased the sensitivity by 50 per cent. A new combination was described, consisting of a bolometer, back of which was placed a thermocouple. ${ }^{6}$ These devices will aid materially in increasing the sensitivity. However, owing to the complexity of operation, no attempt was made to utilize them in a temporary installation such as was used in the present work. In fact, owing to the temporary nature of the present radiometric installation, it was not possible to use the full sensitivity that was available in the equipment employed.

Among the photoelectric receivers, Case's thalofide cell was investigated. ${ }^{7}$ This cell has a sharp maximum of sensitivity for radiation of wave lengths at about $\mathrm{I} \mu$, which property may prove of-interest in some lines of stellar radiometry.

\section{RECENT TESTS OF THERMOCOUPLE MATERIAL}

Before making up the vacuum thermocouples for the present investigation it was of interest to try material of different thermoelectric power to determine the effect of heat conduction upon the radiation sensitivity. Some material of great ductility but low thermoelectric power was obtainable in much smaller diameters than the wires of bismuth and bismuth alloys previously used. It was therefore of interest to determine whether by using the finest wire to reduce conduction, and thus conserve the heat at the juncture, the efficiency of the receiver could be increased. In making the test samples of various metals were joined in series, thus eliminating the question of internal resistance, which remained the same throughout the test.

The materials tested were connected in series as follows: $60 \mathrm{Au}$ +40 Pd: $90 \mathrm{Pt}+$ Io Rh: $\mathrm{Bi}: 95 \mathrm{Bi}+5 \mathrm{Sn}: 97 \mathrm{Bi}+3 \mathrm{Sb}: 90 \mathrm{Pt}+$ Io $\mathrm{Rh}$. The gold-palladium and the platinum-rhodium alloy wires ${ }^{8}$

5 B. S. Bulletin, 13, p. 423; 1916.

J. Wash. Acad. Sci., 6, p. 473; 1916. B. S. Bulletin, 14, p. 532; 1918.

7 B. S. Sci. Papers, 16, p. 253; 1920.

${ }^{8}$ From Baker and Co., Newark, N. J. 
were $0.02 \mathrm{~mm}$ in diameter. The alloys of bismuth-tin and bismuthantimony were in the form of fine wire ${ }^{9}, 0.025 \mathrm{~mm}$ in diameter.

The pure bismuth was in the form of a strip made by pressing a wire flat between glass plates and cutting it with a razor, as described in the previous paper. ${ }^{10}$ The strip was approximately $0.07 \mathrm{~mm}$ wide by 0.01 to $0.02 \mathrm{~mm}$ thickness. From previous tests it appears that the low radiation sensitivity of this sample (see Table I) was owing to its large cross section. Moreover the receiver did not appear to be thoroughly covered with lampblack. The receivers were about $0.5 \mathrm{~mm}$ in diameter, made of small globules of tin (or Woods alloy for the bismuth alloys), pressed flat (while molten) between thin plates of mica, as described in previous papers, and painted with lampblack.

The radiation sensitivity test was made in air by focusing upon the receiver an artificial star, which consisted of a pinhole in a thin aluminum plate in front of an acetylene flame.

The results of this test are summarized in Table $\mathrm{I}$, in which column 2 gives the thermoelectric power in microvolts, column 3 gives the ratio of the emf's, and column 4 gives the ratio of galvanometer deflections in terms of that of the thermojunction of $\mathrm{Au}+\mathrm{Pd}: \mathrm{Pt}+\mathrm{Rh}$, taken as a standard.

TABLE 1.-Comparison of Stellar Thermocouples

\begin{tabular}{|c|c|c|c|}
\hline Elements & $\begin{array}{c}\text { Thermo- } \\
\text { electric } \\
\text { power }\end{array}$ & $\begin{array}{c}\text { Ratio of } \\
\text { emf's }\end{array}$ & $\begin{array}{l}\text { Radlation } \\
\text { Sensi- } \\
\text { tivity }\end{array}$ \\
\hline & $\mathbf{m v}$ & & \\
\hline$A u+P d: P t+R h . \ldots \ldots \ldots \ldots$. & 32 & 1.0 & 1.0 \\
\hline $\mathbf{P t}+\mathrm{Rh}: \mathrm{Bi} \ldots \ldots \ldots \ldots \ldots$ & 85 & 2.65 & 2. 85 \\
\hline 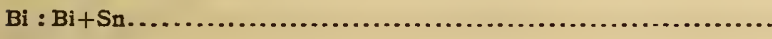 & 137 & 4. 28 & 3. 65 \\
\hline 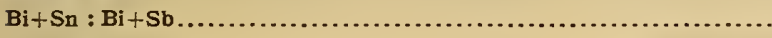 & 129 & 4.04 & 5. 35 \\
\hline 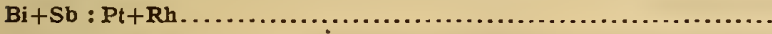 & 74 & 2. 31 & 2. 56 \\
\hline
\end{tabular}

The results are interesting in showing that the radiation sensitivity is closely proportional to the thermoelectric power (which is to be expected), but there seems to be no marked gain in sensitivity from reduction of thermal conduction. In the case of the pure bismuth the wire was not as thin as it could be made, and hence there is reason for believing that the efficiency would have been higher if a finer wire had been used. The thermocouples of the bismuth-alloy wire are interesting in having a radiation sensitivity

${ }^{9}$ From Adam Hilger (I,ta.), 75 A Camden Road, London, England.

10 B. S. Bulletin, 11, p. 613; 1914 
about 20 per cent higher than would be expected from the thermoelectric power. This seems to show an improvement in sensitivity as a result of elimination of heat conduction. However, there is one more factor to be considered, namely, internal resistance. In changing from pure bismuth to the bismuth alloys the thermal emf is increased only about 60 per cent, whereas the internal resistance is increased threefold to fourfold. Hence, from the nature of the thermocouple required for stellar radiometry it appears to be more efficient to use the pure bismuth wire. This conclusion is substantiated by the tests described in previous papers and by the results on the thermocouples used in the present investigation. For example, the data in Table 2 show that the stellar thermocouple of $\mathrm{Au}+\mathrm{Pd}$ alloy in mounting No. Io (evacuated and ready for use) was only half as sensitive as the thermocouple of $\mathrm{Bi}$ in mounting No. 7, which was used seven years ago. Furthermore, the radiation sensitivity of the thermocouples of the alloys of $\mathrm{Bi}$ is not markedly higher than that of the pure $\mathrm{Bi}$, although they have a 57 per cent higher thermoelectric power.

In a recent test of a thermocouple of silver and $0.13 \mathrm{~mm}$ tellurium (from Dr. P. W. Bridgeman) against a similar couple of o.I $\mathrm{mm}$ bismuth (receivers of tin 1.2 by $2.2 \mathrm{~mm}$ ) the radiation sensitivity of the tellurium-silver couple was only twice that of the standard bismuth-silver couple, whereas its resistance was more than ro times that of the bismuth couple.

In view of the results mentioned on a preceding page, showing an increased radiometer efficiency as a result of utilizing reradiation of one receiver upon another (one receiver back of the other), it is of interest to describe some observations showing the effect of convection in reducing the radiation sensitivity when one receiver is back of the other.

In the present tests a regular stellar thermocouple was used, with receivers $(0.5 \mathrm{~mm}$ in diameter) blackened on the front and bright on the rear side. The left $(L)$ receiver, which was used as a standard of comparison, was a trifle larger than the right $(R)$ receiver, which was under investigation. A reflector consisting of a small globule of tin attached to a fine wire for a support and pressed flat ( $0.5 \mathrm{~mm}$ diameter) but unpainted was placed at different distances back of the right $(R)$ receiver. The tests were made in air at atmospheric pressure. In a vacuum convection and conduction would be reduced. It was found that when the reflector was $0.5 \mathrm{~mm}$ from the receiver the radiation sensitivity was reduced by 30 per cent, while at a distance of I $\mathrm{mm}$ the 
reduction in sensitivity is still appreciable ( 5 per cent). The intention was to paint the rear side of the front receiver (which, however, would increase its emissivity) with lampblack in order to absorb the reradiated energy which was returned by the reflector, placed back of the receiver as just described. However, from the tests just described it seemed doubtful whether, in this particular form of radiometer, the addition of a reflector to utilize the reradiated energy would accomplish much more than to compensate for the increased emissivity caused by blackening the rear side of the receiver. Hence the receivers were used without reflectors.

\section{DESCRIPTION OF VACUUM THERMOCOUPLES USED IN THE PRESENT WORK}

The vacuum containers for the thermocouples were of the same general design used in the previous work. Four containers were taken to the observatory, a distance of 2500 miles, without breakage. No vacuum pump was taken (and none was available without going a long distance from the observatory) in order to demonstrate that metallic calcium is a reliable means of vacuum maintenance. ${ }^{11}$

An electric heater was provided for heating the metallic calcium to incandescence. It consisted of a thin porcelain tube about Io $\mathrm{cm}$ long and $\mathrm{I} .5 \mathrm{~cm}$ internal diameter. On the outside of this tube was wound about $2 \mathrm{~m}$ of thin $(0.2 \mathrm{~mm})$ platinum wire, having a resistance of $\mathrm{I} 2 \mathrm{ohms}$. This was covered with alundum cement, such as is used in pyrometric work. A small rheostat was provided and the whole operated on a I ro-volt circuit. It required less than 2 amperes to raise this heater to a low red temperature, and being of low heat capacity this was accomplished in a few minutes.

The evacuation was tested by means of an induction coil as previously described. The containers leaked but little, as was evidenced by the cathode fluorescence of the glass that continued for days when the calcium was not heated. In practice, the calcium evacuator was heated on the afternoon preceding the observations.

Container No. 7 remained the same as used in the previous measurements, except that about two years ago a new quartz tube containing new metallic calcium was provided. ${ }^{12}$ The

11 B. S. Sci. Papers, 17, p. 187; r921.

12 B. S. Sci. Papers, 17, p. 187; 1921.

$93132^{\circ}-22-2$ 
thermocouples were of flat material as described in the previous paper.

Container No. 8 was No. 6, previously used, but with new thermocouples (see Table 2).

Containers Nos. 9 and Io were new with the fluorite windows attached by means of Boltwood's ${ }^{13}$ low vapor pressure cement. This cement has a low melting point which enables one to attach the fluorite without cracking it.

The mounted container is shown in Fig. I, in which $C a$ represents the quartz tube containing the metallic calcium, $F$ the fluorite window, $T$ the thermopile, and $P$ the potential terminals for testing the evacuation by means of an induction coil, automobile spark coil, or a transformer of 2000 to to ooo volts. For further details of construction and manipulation the reader is referred to previous papers. ${ }^{14}$

Two thermocouples were placed in each of the three new mountings. Either one of these could be used without delay in changing the connections. As shown in the lower left-hand corner of Fig. 4 these thermocouples were bent $U$-shaped, so that the two junctures were close $(0.5$ to $I \mathrm{~mm})$ together, in order to facilitate exposing them alternately to the star image, as previously described. ${ }^{15}$ Only fine wires of the alloys of bismuth (with tin and with antimony) were at hand, and these were very brittle, especially the alloys with antimony. Furthermore, difficulty was experienced in attempting to solder the $\mathrm{Bi}+\mathrm{Sb}$ wire to the silver wire (used to reduce the resistance) with Wood's alloy. As finally constructed the central $U$-shaped part of the thermocouple was made of $\mathrm{Bi}+\mathrm{Sb}$ wire about $2 \mathrm{~mm}$ long and the two end pieces of $\mathrm{Bi}+\mathrm{Sn}$ wire about $1.5 \mathrm{~mm}$ long. The junctures were made by means of globules of Wood's alloy, pressed flat between thin plates of mica, as already described. These couples were then soldered to the silver wires, which were coiled to take up any mechanical vibrations caused by handling. Even with this precaution mounting No. $8 \mathrm{had}$ to be remade four times, involving the construction of at least 20 thermocouples before a pair was obtained for shipment. It may be added that this material was so fragile that the receptacle containing the four mountings was carried by hand to the observing station.

\footnotetext{
${ }^{13}$ From Prof. B. B. Boltwood, Yale University, New Haven, Conn.

14 B.S. Bulletin, 11, p. 131, 1914; 11, p. 613; 1915.

${ }^{15}$ See Fig. 2, B. S. Bulletin, 11, p. 622; 1914.
} 
Scientific Papers of the Bureau of Standards, Vol. 17

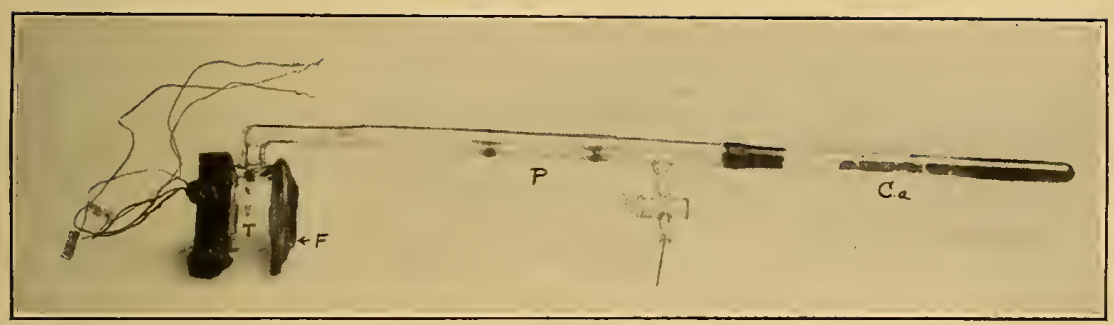

FIG. I-Stellar thermocouple, $T$, in evacuated glass container 
A summary of the constants, including the radiation sensitivity, of the (freshly evacuated) thermocouples is given in Table 2. They are of interest in showing the uniformity of radiation sensitivity that may be expected in thermocouples constructed of the same material. The receivers were made $0.5 \mathrm{~mm}$ in diameter, which was larger than previously used, thinking it might be more efficient in case of change in focus of the star image. But this proved detrimental, because the time to attain a maximum deflection was greatly prolonged. Receiver No. I of mounting No. Io was the quickest acting (2 secs.) of the U-shaped couples, and it was used for all the measurements recorded in this paper.

TABLE 2.-Summary of Data on Stellar Thermocouples

\begin{tabular}{|c|c|c|c|c|c|}
\hline Mounting & Thermocouple & $\begin{array}{l}\text { Size of } \\
\text { receiver }\end{array}$ & $\begin{array}{l}\text { Resist- } \\
\text { ance of } \\
\text { couple }\end{array}$ & $\begin{array}{l}\text { Galva- } \\
\text { nometer } \\
\text { deflec- } \\
\text { tion }\end{array}$ & Remarks \\
\hline No. $7 .$. & $\begin{array}{l}\text { No.1.......... } \\
\text { No.2........ }\end{array}$ & $\begin{array}{r}\text { mam } \\
0.4 \\
.3\end{array}$ & $\begin{array}{r}\text { ohms } \\
11.3 \\
4.6\end{array}$ & $\begin{array}{r}\mathrm{cm} \\
68 \\
60\end{array}$ & $\begin{array}{l}\mathbf{B i}+\mathbf{S n}: \mathbf{B} \mathbf{i}+\mathbf{S b} \\
\mathbf{B i}: \mathbf{P t}\end{array}$ \\
\hline No. 8.. & $\begin{array}{l}\text { No.1 } 1 \ldots \ldots \ldots \\
\text { No. } 2 \ldots \ldots \ldots\end{array}$ & $\begin{array}{l}.6 \\
.4\end{array}$ & $\begin{array}{l}22.7 \\
16.2\end{array}$ & $\begin{array}{l}68 \\
76\end{array}$ & $\begin{array}{l}\mathrm{Bi}+\mathrm{Sn}: \mathrm{Bi}+\mathrm{Sb} \\
\mathrm{Bi}+\mathrm{Sn}: \mathrm{Bi}+\mathrm{Sb}\end{array}$ \\
\hline No. 9.. & $\begin{array}{l}\text { No. } 1 \ldots \ldots \ldots \\
\text { No. } 2 \ldots \ldots \ldots\end{array}$ & $\begin{array}{l}.6 \\
.4\end{array}$ & $\begin{array}{l}19.8 \\
15.2\end{array}$ & $\begin{array}{l}58 \\
60\end{array}$ & $\begin{array}{l}\mathrm{Bi}+\mathrm{Sn}: \mathrm{Bi}+\mathrm{Sb} \\
\mathrm{Bi}+\mathrm{Sn}: \mathrm{Bi}+\mathrm{Sb} \text { Good action }\end{array}$ \\
\hline No. $10 .$. & $\begin{array}{l}\text { No. } 1 \ldots \ldots \ldots \\
\text { No. } 2 \ldots \ldots \ldots\end{array}$ & .3 & $\begin{array}{l}19.3 \\
2.43\end{array}$ & $\begin{array}{l}68 \\
29\end{array}$ & $\begin{array}{l}\mathbf{B i}+\mathbf{S n}: \mathbf{B i}+\mathbf{S b} \text { Best; quickest action } \\
\mathbf{A u}+\mathbf{P d}: \mathbf{P t + R} \mathbf{R}\end{array}$ \\
\hline
\end{tabular}

\section{DESCRIPTION OF THE TRANSMISSION SCREENS}

The function of the screens is to transmit radiation extending over fairly narrow regions of the spectrum. By means of such screens, which, either singly or in combination, are placed in front of the thermocouples, one can obtain some idea of the spectral energy distribution of stars. Screens were selected which had a uniformly high transmission over a fairly narrow region of the spectrum, terminating abruptly in complete opacity in the rest of the spectrum. By proceeding in this manner no correction was necessary to the observations other than that for surface reflection, which amounts to about 9 per cent for the two surfaces of the screen. A slight amount of dust will raise the reflection losses to io per cent, or even higher. The screens selected have the following properties:

FLUORITE, which was used as the window of the vacuum container, transmits uniformly all radiations from the extreme ultra-violet to $10 \mu$ in the infra-red. 
QUARTZ, thickness $4.77 \mathrm{~mm}$, is transparent to all radiations from the extreme ultra-violet to $4 . \mathrm{I} \mu$ in the infra-red (see curve A, Fig. 2). This gives the spectral radiation extending from $0.3 \mu$ to $4 . \mathrm{I} \mu$

WATER, thickness $\mathrm{I} \mathrm{cm}$, in a cell containing thin quartz windows, is transparent from the extreme ultra-violet to $I .4 \mu$ in the infra-

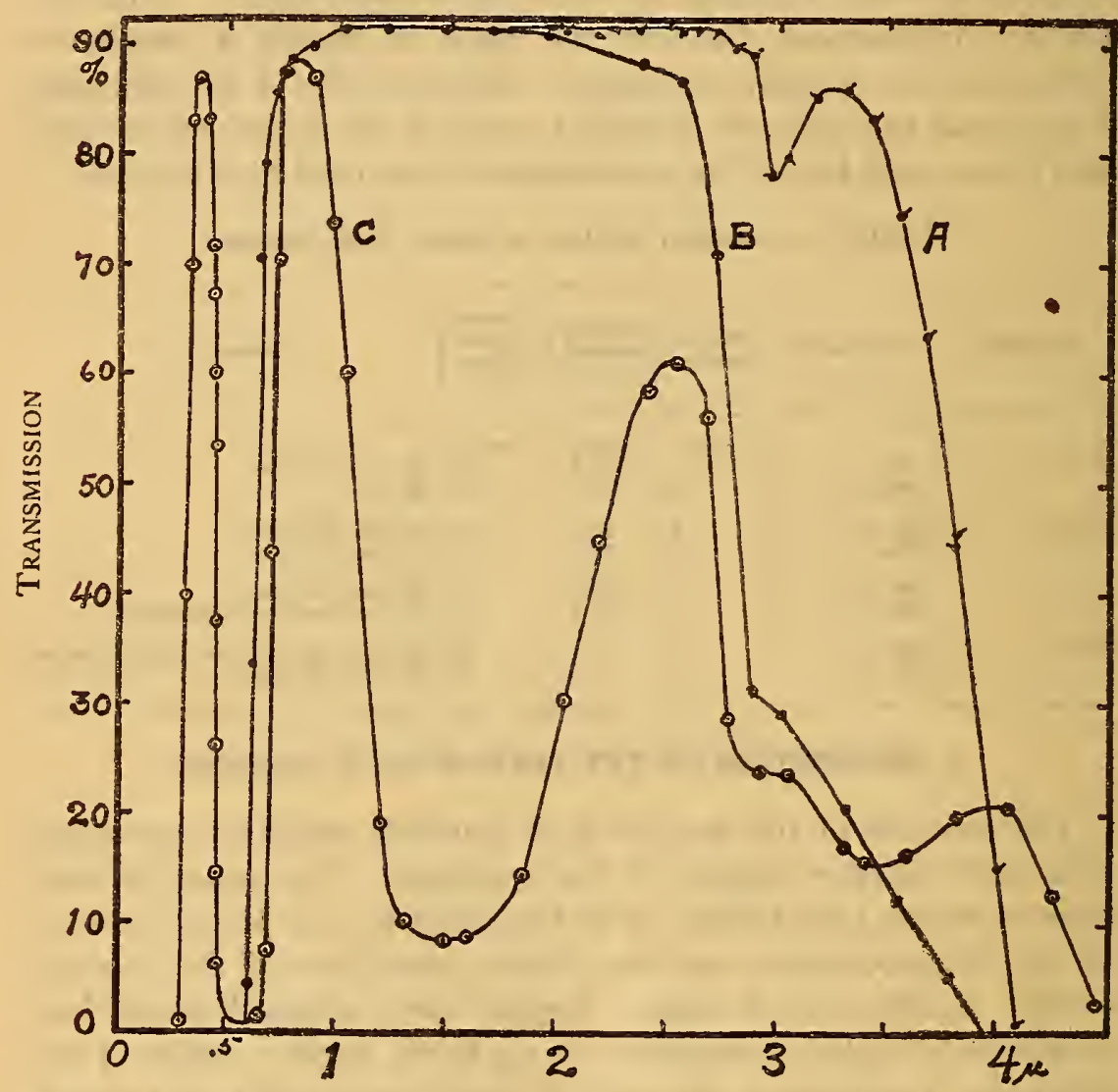

FIG. 2.-Transmission curves of screens: $A$, quartz; $B$, red glass; $C$, blue-purple glass

red (see curve $C$, Fig. 3 ). Used as a screen this gives the spectral radiation between $0.3 \mu$ and $\mathbf{I} .4 \mu$.

YelLOW GLASS, Schott's Jena 556o, thickness $2.97 \mathrm{~mm}$, is opaque to radiations of wave lengths less than $0.43 \mu$ (see curve $A$, Fig. 3). The infra-red transmission is not very abrupt. Hence it was used in combination with the water cell, giving the spectral radiation between $0.43 \mu$ and $\mathrm{I} .4 \mu$.

RED GLASS, Schott's Jena 45I2, thickness $1.97 \mathrm{~mm}$, is opaque to radiations of wave lengths less than $0.6 \mu$ (see curve $B$, Fig. 2). 
It was used in combination with the water cell, giving the spectral radiation between $0.6 \mu$ and $I .4 \mu$. The difference between the galvanometer deflection when the water cell is interposed and when the water cell plus the red glass are interposed (corrected for reflection) gives the radiation in the spectral region from $0.3 \mu$ to $0.6 \mu$. Similarly, the difference between the galvanometer deflec-

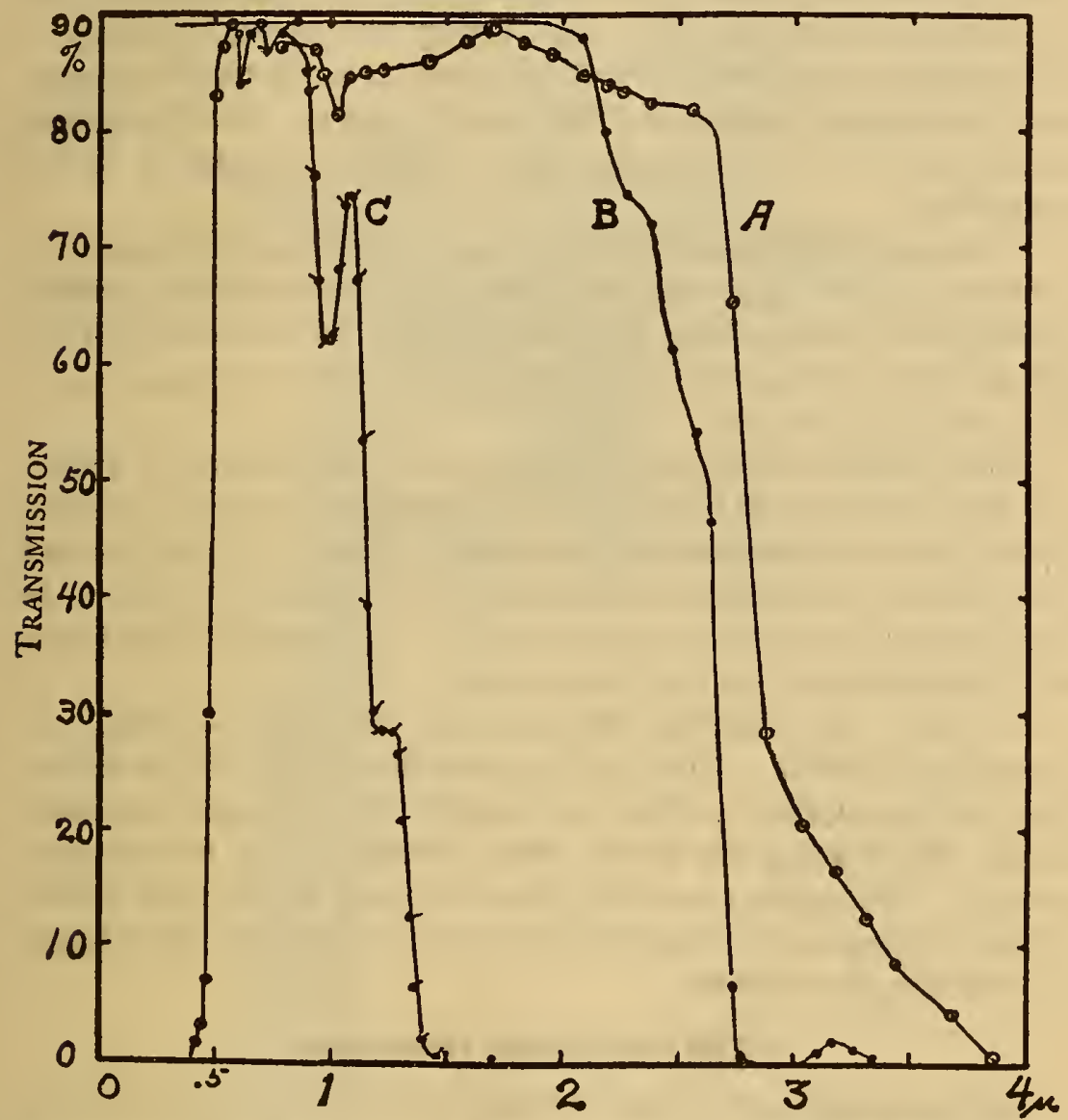

FIG. 3.-Transmission curves of screens: $A$, yellow glass; $B$, pyrex glass; $C$, water, $I \mathrm{~cm}$ in thickness

tion for the water cell plus yellow glass and the deflection for the water cell plus red glass represents the spectral radiation between $0.43 \mu$ and $0.60 \mu$.

PyREX Glass, Corning, thickness $1.19 \mathrm{~cm}$, terminates very abruptly in its transmission at $2.8 \mu$ (see curve $B$, Fig. 3 ). However, the sample used contained striæ and it was used in the measurements of the radiation from only one star. 
Blue-PurPle-Ultra Glass, Corning, G 585 , thickness 3 . 5 mm, when used in combination with the water cell gives the radiation in two high narrow transmission bands, at $0.36 \mu$ and $0.83 \mu$, respectively (see curve $C$, Fig. 2). Using in addition the abovementioned red or yellow glass, the radiation in the spectral region from $0.7 \mu$ to $I .4 \mu$ is obtained. Hence, by proper combination of the data one can obtain the radiation intensities between $0.6 \mu$ and $0.7 \mu$ and between $0.3 \mu$ and $0.4 \mu$. Owing to a constant change in galvanometer sensitivity, which required so much time in repeating observations when using the various screens, this blue-purple screen was used in only one series of measurements of stellar radiation.

By means of these screens it was possible to obtain the radiation intensity in the spectrum from the extreme ultra-violet (which is limited by atmospheric transmission and the low reflectivity of the mirrors) at $0.3 \mu$ to $0.43 \mu, 0.43 \mu$ to $0.60 \mu, 0.60 \mu$ to $\mathrm{I} .4 \mu, \mathrm{I} .4 \mu$ to 4.I $\mu$, and $4 . \mathrm{I} \mu$ to $\mathrm{IO} \mu$.

These screens, which were in the form of disks $25 \mathrm{~mm}$ in diameter, were mounted in brass supports, which in turn were mounted upon brass rods and sleeves, as shown in Fig. 4. Each rod and sleeve could be rotated independently by means of a lever. In this manner the various screens could be interposed (either singly or in combination) in the optical path.

In Fig. 4 the vacuum thermocouple mounting of Fig. I is shown in its holder. The small eyepiece to the right is for setting the thermojunction on the star image. The incandescent lamp is for illuminating the levers when operating the transmission screens. The whole mounting takes the place of the plate holder in the telescope, and it required only a few minutes to interchange it with the plate holder.

\section{THE REFLECTING TELESCOPE}

The telescope used in this investigation was the $40-i n$. (100 cm) reflector of the Lowell Observatory, which is at an elevation of $7300 \mathrm{ft}$. The focal length is $22 \mathrm{I}$ in. $(550 \mathrm{~cm})$. There is a diagonal mirror which reflects the star image to the side of the tube. The mirrors were newly silvered and in an excellent condition. The elevation being almost twice that of the station previously used, atmospheric scattering and absorption should be appreciably reduced. At this station there is a rainy season during two of the summer months, and this summer the cloudiness 


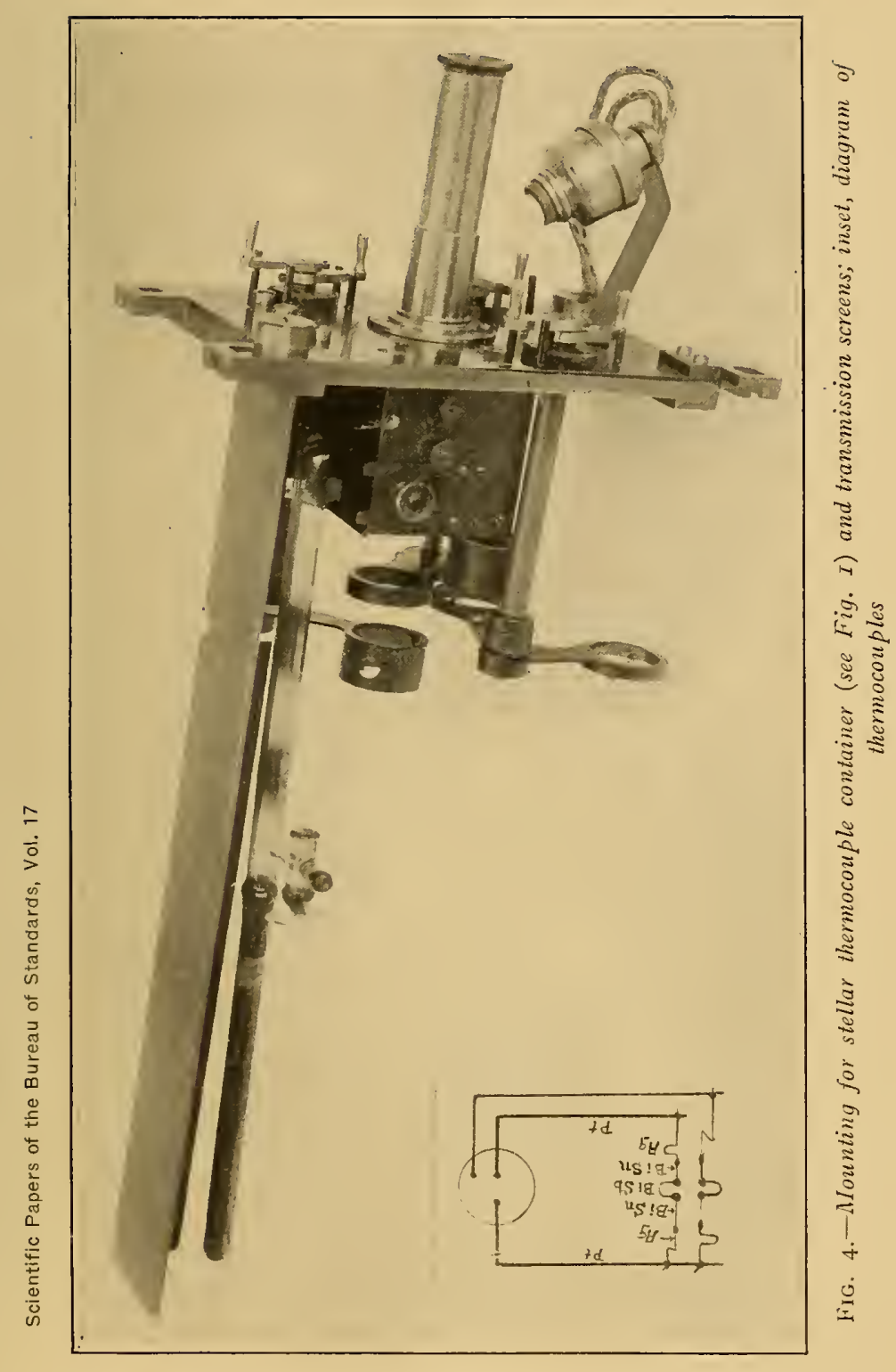


continued longer than usual, thus encroaching upon the time set for making the experiments. For this reason the observations were not made under such ideal conditions from night to night as was hoped. However, observations made on the same night are consistent in showing small gradations in the infra-red component radiation, corresponding with the small gradations in spectral types (for example, B2 and B8) of stars. There are apparently slight inconsistencies in the water cell transmissions in comparing class $\mathrm{B}$ and class $\mathrm{A}$ stars. While this may really be true, and perhaps is to be expected, further observations will be necessary to decide this question. This form of stellar radiometer is very sensitive to slight changes in atmospheric transparency which are scarcely perceptible to the eye of even an experienced astronomer.

\section{MEASUREMENT OF THE TOTAL RADIATION FROM STARS}

The method of observation consisted in projecting the star image alternately upon the two junctures of the thermocouple by turning the slow motion screws of the plate holder and noting the change in the galvanometer deflection as observed with the telescope scale, which was at a distance of $2 \mathrm{~m}$.

In the present investigation the total radiation measurements seemed of little interest. They constitute the measurements made without the transmission screens, and they are given in Table 3. The size of the deflections are of the same order as previously observed, verifying previous conclusions that red stars emit far more total radiation than blue stars of the same visual magnitude. For example, the observations of October 6 show that $\mu$ Geminorum emits about four times as much total radiation as $\epsilon$ Geminorum, which has the same visual magnitude.

The great difference in the total radiation from stars is well illustrated in Table 4 , which gives a comparison of the total radiation from groups of stars having closely the same visual magnitude.

Observations of total radiation were made on 13 stars not previously observed. Since considerable time was required to complete a series of observations in order to determine the spectral radiation, no attempt was made to observe faint stars. 
TABLE 3.- Total Radiation From Stars; also Transmission through a $1 \mathrm{~cm}$ Cell of Water. The Time is "Standard Mountain Time"

\begin{tabular}{|c|c|c|c|c|c|c|c|c|c|}
\hline Object & $\begin{array}{r}\text { Date } \\
\text { (1921) }\end{array}$ & Hour & $\begin{array}{l}\text { Mag- } \\
\text { ni- } \\
\text { tude }\end{array}$ & $\begin{array}{l}\text { Ob- } \\
\text { served } \\
\text { deflec- } \\
\text { tion }\end{array}$ & $\begin{array}{l}\text { Maxi- } \\
\text { mum } \\
\text { devia- } \\
\text { tion } \\
\text { from } \\
\text { the } \\
\text { mean } \\
\text { value }\end{array}$ & $\begin{array}{c}\text { Galva- } \\
\text { nom- } \\
\text { eter } \\
\text { sensi- } \\
\text { tivity } \\
\mathbf{i}= \\
\mathbf{k} \cdot 10-10\end{array}$ & $\begin{array}{c}\text { Galva- } \\
\text { nom- } \\
\text { eter } \\
\text { deflec- } \\
\text { tion } \\
\text { tor } \\
i= \\
1.10-10\end{array}$ & $\begin{array}{l}\text { Spec- } \\
\text { tral } \\
\text { class } \\
\text { of } \\
\text { star }\end{array}$ & $\begin{array}{l}\text { Trans- } \\
\text { mis- } \\
\text { sion } \\
\text { of } \\
\text { water } \\
\text { cell }\end{array}$ \\
\hline $\begin{array}{l}\alpha \text { Aquilae .......... } \\
\alpha \text { Scorpil........... } \\
\alpha \text { Lyrae .......... } \\
\beta \text { Andromedae.... }\end{array}$ & $\begin{array}{l}\text { Sept. } 27 \\
\text { Oct. } 5 \\
\text { Sept. } 27 \\
\text { Sept. } 27 \\
\text { Sept. } 27\end{array}$ & $\begin{array}{r}7: 15 \\
8: 30 \\
7: 45 \\
8: 45 \\
11: 45\end{array}$ & $\begin{array}{l}0.9 \\
1.22 \\
.14 \\
2.37\end{array}$ & $\left\{\begin{array}{l}\mathrm{cm} \\
1.70 \\
1.61 \\
7.60 \\
3.05 \\
2.33\end{array}\right.$ & $\begin{array}{l}0.15 \\
.04 \\
: 18 \\
.15 \\
.15\end{array}$ & $\begin{array}{l}1.11 \\
1.16 \\
1.16 \\
1.18 \\
1.05\end{array}$ & $\begin{array}{l}\mathrm{cm} \\
1.89 \\
1.87 \\
8.82 \\
3.60 \\
2.45\end{array}$ & 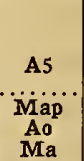 & $\begin{array}{r}\text { Per } \\
\text { cent } \\
73 \\
69 \\
33 \\
75 \\
41\end{array}$ \\
\hline 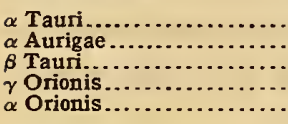 & $\begin{array}{lr}\text { Sept. } & 27 \\
\text { Oct. } & 3 \\
\text { Oct. } & 3 \\
\text { Oct. } & 3 \\
\text { Oct. } & 3\end{array}$ & $\begin{array}{l}13: 15 \\
12: 30 \\
13: 00 \\
13: 15 \\
13: 30\end{array}$ & $\begin{array}{l}1.06 \\
.21 \\
1.78 \\
1.70 \\
.92\end{array}$ & $\begin{array}{r}5.80 \\
3.81 \\
.66 \\
.53 \\
12.40\end{array}$ & $\begin{array}{l}.20 \\
.10 \\
.06 \\
.04 \\
.20\end{array}$ & $\begin{array}{l}1.04 \\
1.29 \\
1.18 \\
1.21 \\
1.21\end{array}$ & $\begin{array}{r}6.03 \\
4.91 \\
.78 \\
.64 \\
15.00\end{array}$ & $\begin{array}{l}\mathrm{K} 5 \\
\text { Go } \\
\mathbf{B} 8 \\
\text { B2 } \\
\text { Ma }\end{array}$ & $\begin{array}{l}42 \\
57 \\
79 \\
82 \\
34\end{array}$ \\
\hline $\begin{array}{l}\beta \\
\theta \text { Orionis } \text { Oris (Nebula). }\end{array}$ & $\begin{array}{ll}\text { Oct. } & 3 \\
\text { Oct. } & 3\end{array}$ & $\begin{array}{l}14: 30 \\
15: 00\end{array}$ & .34 & $\begin{array}{r}2.08 \\
\pm .02\end{array}$ & .05 & 1.39 & 2.89 & B8 p & 6 \\
\hline$\alpha$ Canis Majoris. . & Oct. 3 & $15: 30$ & 1.58 & 6.40 & .20 & 1.66 & 10.62 & Ao & 65 \\
\hline 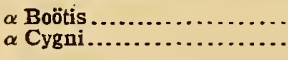 & $\begin{array}{ll}\text { Oct. } & 5 \\
\text { Oct. } & 5\end{array}$ & $\begin{array}{l}7: 15 \\
9: 45\end{array}$ & $\begin{array}{l}. .24 \\
1.4\end{array}$ & $\begin{array}{l}7.10 \\
1.06\end{array}$ & $\begin{array}{l}.25 \\
.04\end{array}$ & $\begin{array}{l}1.14 \\
1.26\end{array}$ & $\begin{array}{l}8.10 \\
1.34\end{array}$ & $\begin{array}{l}\text { Ko } \\
\mathbf{A} 2\end{array}$ & $\begin{array}{l}47 \\
76\end{array}$ \\
\hline 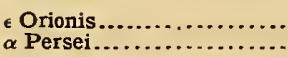 & $\begin{array}{ll}\text { Oct. } & 6 \\
\text { Oct. } & 6\end{array}$ & $\begin{array}{l}14: 00 \\
14: 20\end{array}$ & $\begin{array}{l}1.75 \\
1.90\end{array}$ & $\begin{array}{l}.43 \\
.45\end{array}$ & $\begin{array}{l}.07 \\
.04\end{array}$ & $\begin{array}{l}1.54 \\
1.66\end{array}$ & $\begin{array}{l}.66 \\
.75\end{array}$ & $\begin{array}{l}\text { Bo } \\
\text { F5 }\end{array}$ & $\begin{array}{l}81 \\
74\end{array}$ \\
\hline$\alpha$ Canis Minoris ............ & Oct. 6 & $15: 00$ & .48 & 1.70 & .08 & 1.57 & 2.67 & F5 & 64 \\
\hline 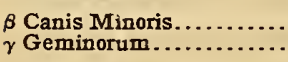 & $\begin{array}{ll}\text { Oct. } & 6 \\
\text { Oct. } & 6\end{array}$ & $\begin{array}{l}15: 15 \\
15: 30\end{array}$ & $\begin{array}{l}13.5 \\
3.09 \\
1.93\end{array}$ & $\begin{array}{l}.25 \\
.47\end{array}$ & $\begin{array}{l}.03 \\
.04\end{array}$ & $\begin{array}{l}1.51 \\
1.51\end{array}$ & .38 & $\begin{array}{l}\text { B8 } \\
\text { A0 }\end{array}$ & \\
\hline$\beta$ Geminorum.. & Oct. 6 & $15: 45$ & 1.21 & 1.46 & .07 & 1.50 & 2.19 & Ko & 58 \\
\hline$\alpha$ Geminorum. & Oct. 6 & $16: 00$ & $\begin{array}{l}1.99 \\
2.85\end{array}$ & .50 & .05 & & 78 & $A$ & n \\
\hline $\begin{array}{l}{ }_{\mu}^{\mu} \text { Geminorum } \\
\epsilon \text { Geminorum } \\
\alpha \text { Leonis } . . . \ldots \ldots \ldots \ldots \ldots \ldots\end{array}$ & $\begin{array}{ll}\text { Oct. } & 6 \\
\text { Oct. } & 6 \\
\text { Oct. } & 6\end{array}$ & $\begin{array}{l}16: 15 \\
16: 45 \\
17: 00\end{array}$ & $\begin{array}{l}3.19 \\
3.18 \\
1.3\end{array}$ & $\begin{array}{r}1.36 \\
.38 \\
.48\end{array}$ & $\begin{array}{l}.09 \\
.03 \\
.09\end{array}$ & $\begin{array}{l}1.55 \\
1.52 \\
1.63\end{array}$ & $\begin{array}{r}2.11 \\
.58 \\
.78\end{array}$ & $\begin{array}{l}\text { Ma } \\
\text { G5 } \\
\text { B8 }\end{array}$ & $\begin{array}{l}41 \\
66\end{array}$ \\
\hline$\gamma$ Leonis.. & Oct. 6 & $17: 15$ & $\begin{array}{l}2.61 \\
3.80\end{array}$ & .61 & .09 & 1.63 & .99 & $\mathbf{K}_{0}$ & \\
\hline $\begin{array}{l}\text { Mars.............. } \\
\text { Venus............. } \\
\beta \text { Iyrae.......... } \\
\lambda \text { Aquarii ........ }\end{array}$ & $\begin{array}{lr}\text { Oct. } & 6 \\
\text { Oct. } & 6 \\
\text { Oct. } & 10 \\
\text { Oct. } & 10\end{array}$ & $\begin{array}{r}17: 25 \\
17: 40 \\
8: 00 \\
8: 45\end{array}$ & $\begin{array}{l}\text { var. } \\
3.84\end{array}$ & $\begin{array}{r}.75 \\
60.20 \\
.21 \\
.65\end{array}$ & $\begin{array}{l}.07 \\
.10 \\
.05 \\
.08\end{array}$ & $\begin{array}{l}1.63 \\
1.63 \\
1.25 \\
1.16\end{array}$ & $\begin{array}{r}1.22 \\
98.30 \\
.26 \\
.75\end{array}$ & $\begin{array}{c}\mathrm{B} 8 \mathrm{p} \\
\mathrm{Ma}\end{array}$ & 67 \\
\hline$\beta$ Pegasi. & Oct. 10 & $9: 10$ & 2.61 & 2.28 & .12 & 1.30 & 2.96 & Mb & 38 \\
\hline
\end{tabular}

By increasing the sensitivity-say, 5 times-thus obtaining deflections of 15 to $20 \mathrm{~mm}$ instead of 3 to $5 \mathrm{~mm}$ as previously observed, it will be possible to determine the spectral energy distribution of a large number of stars which could not be measured accurately with the present temporary radiometric installation. As already explained, the present apparatus was hastily assembled to try out a specific problem, and advantage could not be taken of the full sensitivity available.

The measurements of the total radiation, and of the transmission through the water cell are given in columns 7 and respectively, of Table $\times 3$ The latter are the ratio of the observed galvanometer deflections without correction for losses by reflection, etc. The 
numerical values are somewhat higher than previously observed. They would be still higher for blue stars if a correction were made for absorption by the silver mirrors.

TABLE 4.-Comparison of the Total Radiation from Stars Having Closely the Same Visual Magnitude

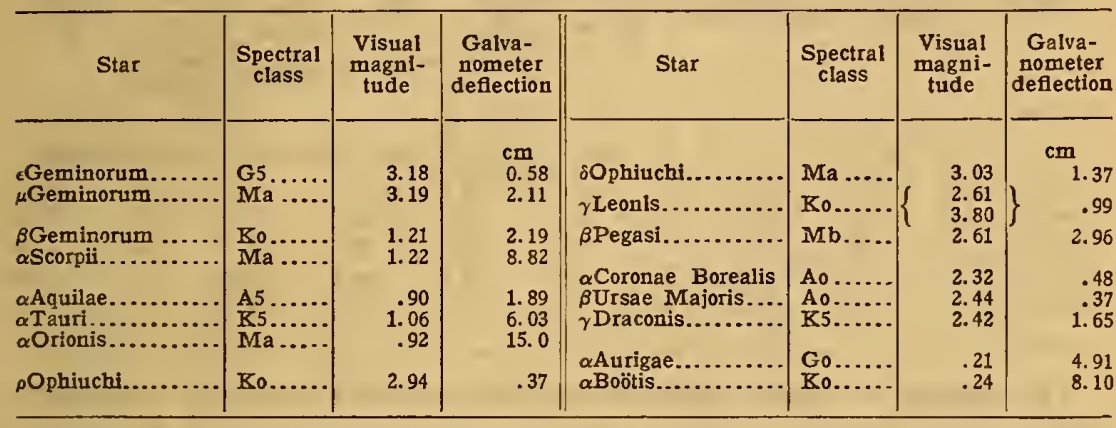

\section{MEASUREMENT OF THE SPECTRAL RADIATION OF 16 STARS}

Under this caption are gathered all the observations of the spectral radiation measurements on 16 stars and various comments relating thereto. A typical example of the spectral component radiation data is given in Table 5, tabulated as follows: Column I gives the range of the spectrum transmitted by the various transmission screens used on a particular star; column 2 gives the observed galvanometer deflections, corrected for losses ( 9 per cent) by reflection from the surfaces of the transmission screens; column 4 gives the "reduced deflection" obtained from column 2, arranged in consecutive order in the spectral ranges given in column 3. After applying a correction for absorption by the two silvered mirrors, column 5 , and an additional correction for atmospheric absorption (entirely uncertain at 4 to ro $\mu$ ), column 6 , the data in the various spectral regions are calculated in per cent of the total radiation, columns 7 and 8 . Finally, in column 9 are given the calculated spectral components in percentage of the total radiation emitted by a black body at the temperature indicated at the top of the column. For this purpose the constant $\mathrm{C}_{2}=\mathrm{I} 4320$ was used. The calculated spectral energy curve, for, say, $3000^{\circ} \mathrm{K}$, was drawn to a large scale on crosssection paper. Similar curves were drawn after applying the spectral transmission data of the various screens. 
TABLE 5.-Spectral Component Radiation Data of $\beta$ Orionis (Rigel)

Magnitude 0.34 ; Class B8p

\begin{tabular}{|c|c|c|c|c|c|c|c|c|}
\hline \multirow{3}{*}{$\begin{array}{l}\text { Observed } \\
\text { spectral } \\
\text { transmission } \\
\text { ranges }\end{array}$} & \multirow{3}{*}{$\begin{array}{c}\text { Ob- } \\
\text { served } \\
\text { galva- } \\
\text { nometer } \\
\text { de- } \\
\text { flection }\end{array}$} & \multicolumn{4}{|c|}{ Galvanometer deflection } & \multicolumn{3}{|c|}{ Percentage of total radiation } \\
\hline & & \multirow[b]{2}{*}{$\begin{array}{c}\text { Consecutive } \\
\text { spectral ranges }\end{array}$} & \multirow[b]{2}{*}{$\begin{array}{c}\text { Reduced } \\
\text { de- } \\
\text { flection }\end{array}$} & \multirow{2}{*}{$\begin{array}{l}\text { Cor- } \\
\text { rected } \\
\text { for } \\
\text { mirrors }\end{array}$} & \multirow{2}{*}{$\begin{array}{l}\text { Cor- } \\
\text { rected } \\
\text { for } \\
\text { mirrors } \\
\text { and at- } \\
\text { mosphere }\end{array}$} & \multicolumn{2}{|c|}{ Observed } & \multirow[b]{2}{*}{$\begin{array}{c}\text { Calcu- } \\
\text { lated for } \\
10000^{\circ} \mathrm{K}\end{array}$} \\
\hline & & & & & & $\begin{array}{l}\text { Cor- } \\
\text { rected } \\
\text { for } \\
\text { mirrors }\end{array}$ & $\begin{array}{c}\text { Cor- } \\
\text { rected for } \\
\text { mirrors } \\
\text { and at- } \\
\text { mosphere }\end{array}$ & \\
\hline$\mu$ & $\mathrm{cm}$ & $\mu$ & $\mathrm{cm}$ & $\mathrm{cm}$ & $\mathrm{cm}$ & Per cent & Per cent & Per cent \\
\hline 0.3 to $10 \ldots \ldots$. & 2. 08 & 0.3 to 0.43 & 0.73 & 1.22 & 1.52 & 45.7 & 51.3 & 49.5 \\
\hline .3 to $4.1 . \ldots$. & 1. 90 & .43 to .6 & .39 & .46 & .53 & 17.2 & 17.9 & 17.5 \\
\hline .3 to $1.4 \ldots$ & 1.47 & .6 to 1.4 & .35 & .37 & .37 & 13.9 & 12.5 & 21.4 \\
\hline .43 to $1.4 \ldots .$. & .74 & 1.4 to 4.1 & .43 & .44 & .54 & 16.5 & 18.3 & 10.8 \\
\hline .6 to $1.4 . \ldots$. & .35 & 4. 1 to 10 & .18 & .18 & 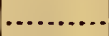 & 6.7 & $\ldots$ & .8 \\
\hline
\end{tabular}

The areas of these curves are proportional to the radiation transmitted by the screens. Hence a comparison can be made between the computed and observed data. Since atmospheric absorption terminates the spectrum at $0.3 \mu$, the calculated spectral energy curves were similarly terminated at $0.3 \mu$. This has no effect upon the spectral energy curves at $3000^{\circ} \mathrm{K}$. But for temperatures of 8000 to $10000^{\circ} \mathrm{K}$ an appreciable amount of the calculated energy lies at wave lengths less than $0.3 \mu$.

The data herewith presented represent spectral energy curves of stars as observed at an altitude of $7300 \mathrm{ft}(2250 \mathrm{~m}$.). In view of the preliminary nature of the measurements, sufficient time was not available to work out fine corrections for atmospheric absorption pertaining to the particular screens used, and thus obtain a more accurate energy distribution of stars as it is outside the earth's atmosphere. In the case of the Sun, in spite of numerous attempts, it has not been possible ${ }^{16}$ to work out satisfactorily the relative spectral energy distribution as it is outside the atmosphere, and it would be even more difficult for blue stars in which the maximum radiation intensity lies in the ultra-violet. Since air is opaque to radiation of wave lengths less than about $0.29 \mu$, it is not known whether radiation of wave lengths less than $0.29 \mu$ is emitted by stars.

\section{SPECTRAL ENERGY DATA ON 16 STARS}

The spectral radiation components are given in Table 6 . The data are arranged according to spectral class, the date of observation being given in Table 3 . Comments on special features of these observations are made under separate captions. 


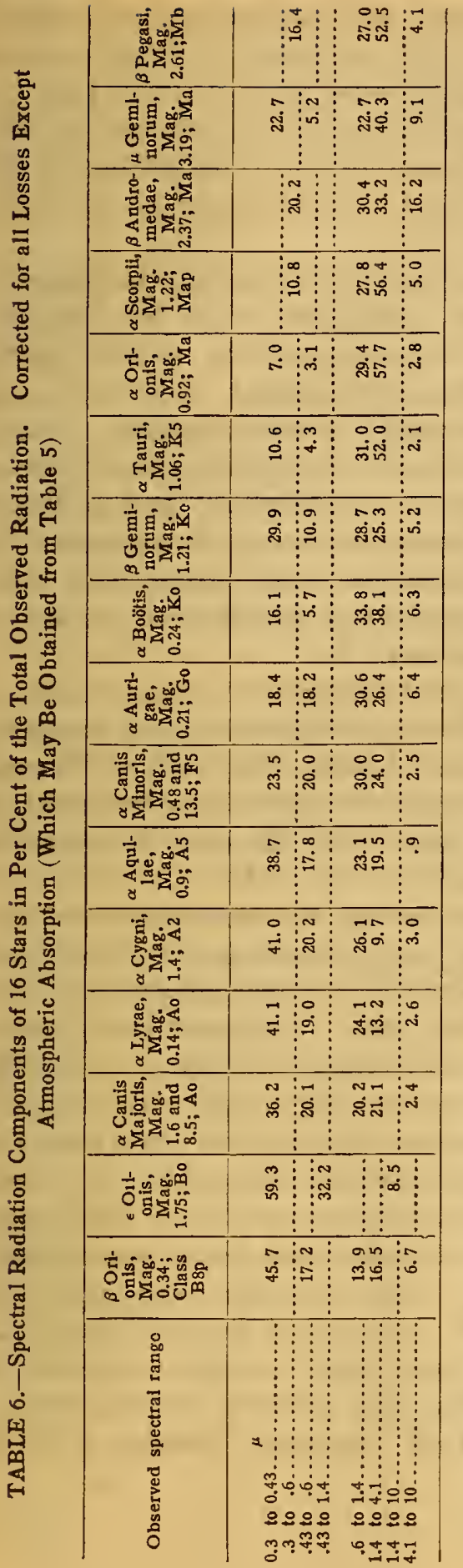

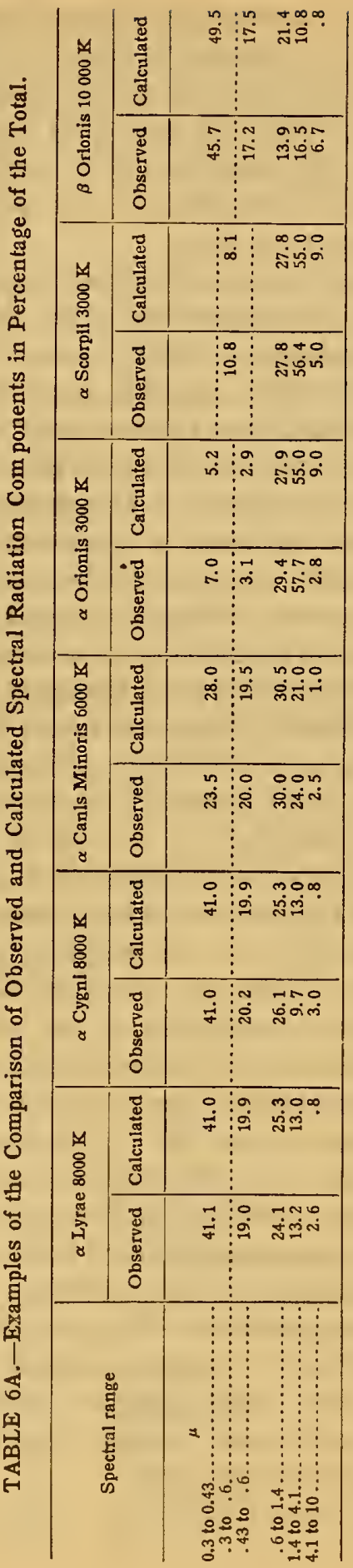


In comparing the observed with the calculated spectral components no attempt is made to obtain agreement in the ultra-violet ( $0.3 \mu$ to $0.43 \mu$ ) and the extreme infra-red ( 4 . I $\mu$ to IO $\mu$ ). In a few cases where the calculated and the computed data are not very close, the temperature is arrived at from a consideration of the ratio of intensities of the spectral ranges $0.43 \mu: 0.6 \mu$ and $0.6 \mu$ : I. $4 \mu$ or I. $4 \mu: 4 . \mathrm{I} \mu$.

In some cases the observed ultra-violet component is extremely large in comparison with the calculated value; for example, $\mu$ Geminorum, which appears to have a peculiar spectral energy distribution. In this case the galvanometer deflections were small and the galvanometer sensitivity was changing. Hence, some of the disagreement is, no doubt, owing to errors of observation. Similarly, $\beta$ Geminorum, $\alpha$ Andromedae and $\beta$ Pegasi appear to have a complex spectral energy distribution. In $\beta$ Pegasi the ultra-violet component seems large. The other components indicate a spectral energy distribution similar to that of a black body at 3000 to $3300^{\circ} \mathrm{K}$.

In numerous cases the agreement between the observed and the calculated values was found to be very close; as, for example, in the $\alpha$-stars of Lyra, Cygnus, Aquila, Canis Minor, Taurus, Orion, and Scorpio. In the latter the spectral components of wave lengths $4 . \mathrm{I} \mu$ to $\mathrm{IO} \mu$ is small, but this may be owing to absorption by the large air mass (see Table 6A.)

In the case of binary stars having large companions of low luminosity - as, for example, $\alpha$ Canis Majoris and $\beta$ Orionis (see Table 5) -the agreement between the observed and the calculated spectral components is not very close. The short wave length components are similar to those of a radiator at 8000 to $10000^{\circ} \mathrm{K}$, whereas the infra-red components are in agreement with those of a radiator at $4000^{\circ} \mathrm{K}$. This, however, does not cast doubt upon the method, but substantiates the conclusions drawn from the transmission observations, made with only the water cell, which show that there is an excess of infra-red radiation in binary stars having companions of low luminosity. This is similar to the radiation from a gas flame-for example, an acetylene flame in which the incandescent carbon particles have their maximum emission in the short wave lengths-whereas the products of combustion, $\mathrm{CO}_{2}$ and water vapor, have their maximum emission $\left(\mathrm{CO}_{2}\right.$ at $4.4 \mu$ ) in the infra-red. 


\section{THE WATER CELL TRANSMISSION DATA}

The measurement of the stellar radiation transmitted by the water cell is a quick and an efficient means of determining the infra-red radiation from stars. The observed transmissions for the blue, B and A class stars (which have no dark companion stars), are as high as 82 per cent, and if a correction had been made for absorption by the silvered mirrors the transmission would be still higher. Since the maximum observable transmission through the water cell can be only about 9I per cent, and since the water cell absorbs but little radiation of wave lengths less than $0.9 \mu$, it appears from this high transmission that in blue stars there is but little infra-red radiation of wave lengths greater than $\mathrm{I} \mu$. Assuming that the energy distribution is similar to that of a black body, the transmission data indicate that the maximum emission must lie in the ultra-violet. From this it appears that much information on the spectral energy distribution of blue stars can be obtained by means of the photographic plate.

In Table 7 the water cell transmissions are arranged in the order of the spectral class of the star. These data confirm previous measurements showing that the red stars are losing heat by radiation much faster than blue stars of the same visual magnitude. In this same table data are given on the absolute magnitudes and the luminosities ${ }^{17}$ of some of the stars. As is to be expected, these data do not contribute much to the present problem.

TABLE 7.-Transmission of Stellar Radiation Through $1 \mathrm{~cm}$ Layer of Water

\begin{tabular}{|c|c|c|c|c|c|c|}
\hline \multirow{2}{*}{ Star } & \multicolumn{2}{|c|}{ Magnitude } & \multirow{2}{*}{$\begin{array}{l}\text { Lumi- } \\
\text { nosity }\end{array}$} & \multirow{2}{*}{$\begin{array}{c}\text { Spectral } \\
\text { type }\end{array}$} & \multirow{2}{*}{$\begin{array}{l}\text { Trans- } \\
\text { misslon }\end{array}$} & \multirow{2}{*}{ Remarks } \\
\hline & Relative & Absolute & & & & \\
\hline $\begin{array}{l}\epsilon \text { Orionis } \ldots \ldots \ldots \ldots \\
\gamma \text { Orionis } \ldots \ldots \ldots \ldots \\
\beta \text { Tauri } \ldots \ldots \ldots \ldots \\
\beta \text { Orionis } \ldots \ldots \ldots \ldots\end{array}$ & $\begin{array}{l}1.75 \\
1.70 \\
1.78 \\
.34 \\
1.00\end{array}$ & & (n......... & $\begin{array}{r}\text { Bo } \\
\mathrm{B} 2 \\
\mathrm{~B} 8 \\
\mathrm{~B} 8 \mathrm{p}\end{array}$ & $\begin{array}{r}\text { Per cent } \\
81 \\
32 \\
79 \\
* 63\end{array}$ & (Rigel) spectroscopic binary \\
\hline$\alpha$ Geminorum .... & $\begin{array}{l}1.99 \\
2.85\end{array}$ & & 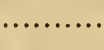 & Ao & 82 & (Castor) \\
\hline$\alpha$ Lyrae........ & .14 & & & Ao & 75 & (Vega) \\
\hline$\alpha$ Canis Majoris .. & $\left\{\begin{array}{c}-1.58 \\
8.5\end{array}\right.$ & & & Ao & *65 & (Sirlus) binary \\
\hline $\begin{array}{l}\alpha \text { Cygni } \ldots \ldots \ldots \ldots \ldots \\
\alpha \text { Aquilae } \ldots \ldots \ldots \ldots \\
\alpha \text { Persei } \ldots \ldots \ldots \ldots\end{array}$ & $\begin{array}{l}1.4 \\
1.9 \\
1.9\end{array}$ & $\begin{array}{l}\cdots \ldots . . . \\
+0.3 \\
+0.3\end{array}$ & $\cdots \cdots \cdots$ & $\begin{array}{l}\text { A2 } \\
\text { A5 } \\
\text { F5 }\end{array}$ & $\begin{array}{l}76 \\
71 \\
74\end{array}$ & $\begin{array}{l}\text { (Deneb) } \\
\text { (Altair) } \\
\text { (Suspected binary) }\end{array}$ \\
\hline$\alpha$ Canis Minoris. & $\left\{\begin{array}{l}.48 \\
13.5\end{array}\right.$ & +3.1 & 5.75 & F5 & $* 64$ & (Procyon) binary \\
\hline $\begin{array}{l}\alpha \text { Aurigae.......... } \\
\text { E Geminorum..... } \\
\beta \text { Geminorum.... }\end{array}$ & $\begin{array}{l}.21 \\
3.18 \\
1.21\end{array}$ & $\begin{array}{l}+.3 \\
-1.0 \\
+.8\end{array}$ & $\begin{array}{r}75.9 \\
251 . \\
47.9\end{array}$ & $\begin{array}{l}\text { Go } \\
\text { G5 } \\
\text { Ko }\end{array}$ & $\begin{array}{r}* 57 \\
66 \\
58\end{array}$ & $\begin{array}{l}\text { (Capella) spectroscopic binary } \\
\text { (Pollux) }\end{array}$ \\
\hline 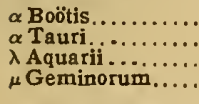 & $\begin{array}{r}.24 \\
1.06 \\
3.84 \\
3.19\end{array}$ & $\begin{array}{r}+.9 \\
+.9 \\
\ldots\end{array}$ & $\begin{array}{r}43.7 \\
43.7 \\
\cdots \cdots \cdots \\
\cdots \cdots \cdots\end{array}$ & $\begin{array}{l}\text { Ko } \\
\text { K5 } \\
\text { Ma } \\
\text { Ma }\end{array}$ & $\begin{array}{l}47 \\
42 \\
47 \\
41\end{array}$ & $\begin{array}{l}\text { (Arcturus) } \\
\text { (Aldebaran) }\end{array}$ \\
\hline $\begin{array}{l}\beta \text { Andromedae.... } \\
\alpha \text { Orionis } \ldots \ldots \ldots \ldots \\
\alpha \text { Scorpil } \ldots \ldots \ldots \ldots \\
\beta \text { Pegasi } . . . \ldots \ldots \ldots\end{array}$ & $\begin{array}{l}2.37 \\
.92 \\
1.22 \\
2.61\end{array}$ & $\begin{array}{r}+1.6 \\
\cdots 3.0 \\
+1.3\end{array}$ & $\begin{array}{c}22.9 \\
\qquad \begin{array}{l}1584 . \\
30.2\end{array}\end{array}$ & $\begin{array}{r}\mathrm{Ma} \\
\mathrm{Ma} \\
\mathrm{Map} \\
\mathrm{Mb}\end{array}$ & $\begin{array}{r}41 \\
34 \\
* 33 \\
38\end{array}$ & $\begin{array}{l}\text { (Betelgeux) } \\
\text { Antares) spectroscopic binary }\end{array}$ \\
\hline
\end{tabular}

${ }^{17}$ Adams and Joy, Astrophys. J., 46, D. 313; 1917. 


\section{THE QUARTZ CELL TRANSMISSION DATA}

The transmission measurements made with the quartz cell corrected for reflection indicate a small amount of infra-red radiation of wave lengths greater than $4 \mu$. In the case of blue stars this amounts to only 2 to 5 per cent. In some cases the observed radiation is greater than the computed, as, for example, in $\alpha$ Lyrae. This is partly owing to errors of observation and also because the correction of 9 per cent for reflection and scattering is too low. The correction for reflection of a screen which is slightly dusty is Io to I I per cent.

In the case of red stars some measurements indicate the preence of infra-red radiations, of wave lengths greater than $4 \mu$, to the extent of Io per cent or more of the total. In some cases the data seem inconsistent (for example, Antares and Aldebaran), but this is probably owing to the large air mass, and hence the large absorption of infra-red rays. . On the other hand, in some of the blue stars the low emissivity at $4 \mu$ to $10 \mu$ is probably owing to selective emission.

The data on $\beta$ Orionis (Table 5 ) confirm the water-cell transmission measurements, showing a large percentage of infra-red radiation from binary stars. Since only a small proportion of the total radiation from stars is of wave lengths greater than $4.5 \mu$, it appears that radiometers with thin quartz windows can be used in stellar radiometry.

\section{BINARY STARS}

In Table 7 the stars marked thus (*) are binaries with companions of low luminosity and so close to the primary star that they could not be measured separately. In all cases the watercell transmissions are low, showing the large amount of infra-red radiation contributed by the dark companion in comparison with the total radiation incident upon the thermocouple. This is especially conspicuous in the case of Sirius. In this connection the following excerpts from Aitken ${ }^{18}$ are appropriate (italics inserted by the writer):

The magnitude of Sirius on the Harvard scale is $-I .5^{8}$. Estimates of the brightness of the companion vary, but it is probably not far from 8.5 on the same scale, a difference of Io.I-magnitude. Accepting these figures, Sirius radiates more than II 000 times as much light as its companion; and, if the parallax $0.376^{\prime \prime}$ is correct, fully 30 times as much as our Sun. Yet, according to the best mass determinations, the bright star is only $2.5^{6}$, the companion 0.74 times as massive as the Sun; and Adams finds that the smaller star, which to the eye seems decidedly the yellower, has the same spectrum (class A) as the bright star. These are facts, as Campbell says, "we are powerless to explain at present."

${ }^{18}$ Aitken, The binary stars, p. 229; 1918. 
From Table 7 it may be noticed that although the visible radiation from the companion is less than $\frac{1}{11.000}$ th that of Sirius, the infra-red radiation is sufficient to reduce the transmission of a class A star from 80 to 65 per cent. In other words, the infra-red radiation from the companion star is much ( 2 to 3 times) greater than that of Sirius.

The method of analysis by means of the water cell may be useful in obtaining information concerning doubtful cases of spectroscopic binaries. For example, Campbell ${ }^{19}$ lists $\alpha$ Persei (class $\mathrm{F}_{5}$ ) as having a suspected variation in radial velocity caused by a companion star. The water-cell transmission is high (74 per cent) and of the order to be expected for a star of its class. Hence, we may infer that the companion star is of the same or a later class (for example, class A), or, what is more likely, that there is no companion star.

\section{STELLAR TEMPERATURES}

The radiation emanating from the photosphere of a star is complex. In some cases-as, for example, $\gamma$ Cassiopeiae (class $\mathrm{B}$ o p) -recently studied by Plaskett, ${ }^{20}$ there are bright emission lines of hydrogen or helium superposed upon a continuous spectrum. It is therefore difficult to determine the spectral energy distribution of the radiation from such stars.

From laboratory experience it is known that in the spark spectra (hypothetical temperature $10000^{\circ} \mathrm{K}$ ) of metals the maximum emisssion is in the ultra-violet. ${ }^{21}$ Similarly, the emission spectrum of an arc between metal electrodes and in the carbon $\operatorname{arc}\left(3600^{\circ} \mathrm{K}\right)$ is in the near infra-red -0.8 to $\mathrm{I} \mu$. The quartz-mercury arc has its maximum emission at $0.365 \mu$. For vacuum tube radiation, hydrogen has its most intense emission lines in the visible and ultra-violet; nitrogen ${ }^{22}$ in the region of $\mathrm{I} \mu$, while the radiation from incandescent helium is confined almost entirely to the emission line at $\mathrm{r} .08 \mu .^{23}$ The radiation from highly attenuated material at a high temperature (for example the incandescent particles of carbon in an acetylene flame) is the most saturated for the short wave lengths. ${ }^{24} \quad$ Even for incandescent solids in the form of rods ${ }^{25}$ (Nernst glowers) it was found that saturation of radiation seems

${ }^{19}$ Lick Obs. Bulletin, 6, p. I7; 1910. Goos, Astronom. Nachtr., 180, p. 57; 1909.

${ }^{20}$ Plaskett, Mo. Notices, Roy. Astro. Soc., 80, p. 771; 1920.

${ }^{21}$ Pflüger, Ann. der Phys. (4), 13, p. 890; 1904.

22 Investigation of infra-red spectra, Publ. No. 35, Carnegie Inst. of Wash., rgo5.

${ }^{23}$ B. S. Bulletin, 9, p. 93 ; 1912.

24 B. S. Bulletin, 7, p. 253 , $59 \times 1 ; 9$, p. 98 , 1912. B. S. Sci. Papers, 15, p. 639; 1920.

${ }^{25}$ B. S. Bulletin, 9, D. IO2; 1912. 
to begin in the short wave lengths. Whether in stars of low density but of infinite thickness of the radiating layer the spectral energy distribution is that of a complete radiator or so-called black body remains to be determined. In the case of stars showing bright spectral lines the emission is evidently highly selective. In the case of incandescent helium the infra-red radiometric measurements on stars might show a peculiar energy distribution owing to the strong emission line at $\mathrm{x} .08 \mu$. From these as well as other considerations one can hardly expect to obtain exact agreement between the calculated and the observed results.

An estimate of the effective temperature of a star was obtained by two methods. The first method consisted in making all corrections to the observations, excepting those for atmospheric absorption, and comparing them with the calculated values, using a solar type star ( $\alpha$ Aurigae, class Go) as a standard. This seems permissible in view of the fact that the observed temperature $\left(6000^{\circ} \mathrm{K}\right)$ of $\alpha$ Aurigae was found to be in close agreement with that assigned to the sun. The stellar temperatures estimated in this manner are given in column 4 of Table 8.

The second method consisted in applying all corrections to the observations, including the one for atmospheric absorption, and comparing the results with the calculated values. Applying factors for atmospheric absorption introduces great irregularities in the observed spectral radiation components. This, no doubt, is owing partly to selective emission of the star and partly to the use of improper transmission factors, which, because of lack of time, could not be determined directly.

The temperature of a star, as estimated from the spectral energy components outside of the atmosphere, extends over a wide range, the average value of which is in good agreement with that obtained by the first method. (See column 3 of Table 8. For each star, the maximum temperature is obtained from the shortest component radiation.)

In the $B$ and $A$ class stars the effective temperatures are no doubt somewhat higher than herewith recorded because of lack of proper corrections for atmospheric absorption.

In the case of the Sun an estimate of the effective temperature of the photosphere has been arrived at by various methods. The estimated temperature varies from $5740^{\circ} \mathrm{K}$, for the total radiation, to $6140^{\circ} \mathrm{K}$, for the spectral radiation method. ${ }^{20}$ Unfortunately,

${ }^{26}$ See recalculations by Coblentz, J. Op. Soc. Am., 5, p. 272; 1921. 
the writer was not equipped to test the present apparatus on the Sun at the station used for measuring stellar radiation. However, the temperatures of the solar type stars (class G) are in good agreement with that of the Sun. For example, the observed temperature of $\alpha$ Aurigae is between $5500^{\circ} \mathrm{K}$ (see Table 8) and $6000^{\circ} \mathrm{K}$. By making proper corrections for atmospheric absorption the effective temperature of the stellar photosphere as observed outside the earth's atmosphere would be several hundred degrees higher. Hence, a conservative estimate is $6000^{\circ} \mathrm{K}$.

TABLE 8.-Stellar Temperatures

\begin{tabular}{|c|c|c|c|c|c|c|c|}
\hline \multirow[b]{2}{*}{ Star } & \multirow{2}{*}{ Class } & \multicolumn{2}{|c|}{ Coblentz } & \multirow{2}{*}{$\begin{array}{c}\text { Wilsing, } \\
\text { Scheiner, } \\
\text { and } \\
\text { Mïnch }\end{array}$} & \multirow{2}{*}{$\begin{array}{l}\text { Nord- } \\
\text { mann } \\
\text { and } \\
\text { Le Mor- } \\
\text { van }\end{array}$} & \multirow{2}{*}{$\begin{array}{l}\text { Nord- } \\
\text { mann }\end{array}$} & \multirow[b]{2}{*}{ Saha } \\
\hline & & Calculated & $\begin{array}{l}\text { Class Go } \\
\text { as stand - } \\
\text { ard }\end{array}$ & & & & \\
\hline 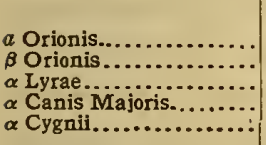 & $\begin{array}{l}\text { Bo } \ldots . . \\
\text { B8p } \ldots \\
\text { Ao } \ldots . . . \\
\text { Ao } \ldots \\
\text { A2 } \ldots . . .\end{array}$ & $\begin{array}{c}{ }^{\circ} \mathrm{K} \\
13000-14000 \\
10000-12000 \\
8000-10000 \\
8000-11000 \\
8000-10000\end{array}$ & $\begin{array}{l}\text { K K } \\
13000 \\
10000 \\
8000 \\
8000 \\
9000\end{array}$ & $\begin{array}{c}\circ \mathrm{K} \\
\cdots \cdots \\
9400 \\
9400\end{array}$ & 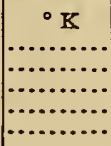 & 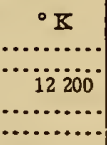 & 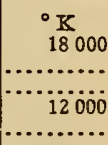 \\
\hline 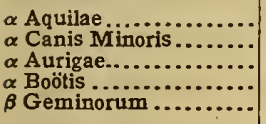 & $\begin{array}{l}\mathrm{A} 5 \ldots . . \\
\mathrm{F} 5 \ldots . . . \\
\mathrm{G} 0 \ldots \\
\mathrm{K}_{0} \ldots \ldots \\
\mathrm{K}_{0} \ldots \ldots\end{array}$ & $\begin{array}{l}7000-9000 \\
5500-7500 \\
5300-6500 \\
3500-4500 \\
4500-7000\end{array}$ & $\begin{array}{l}8000 \\
6000 \\
6000 \\
4000 \\
5500\end{array}$ & $\begin{array}{l}8100 \\
7200 \\
7100 \\
3700 \\
4900\end{array}$ & $\left\{\begin{array}{l}\ldots \ldots \ldots \\
\ldots \ldots \ldots \\
\ldots \ldots \ldots \\
\ldots \ldots \ldots \\
\ldots \ldots \ldots \ldots\end{array}\right.$ & & $\because$ \\
\hline 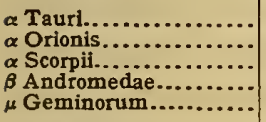 & $\begin{array}{l}\mathrm{K} 5 \ldots \\
\mathrm{Ma} \ldots \\
\mathrm{M} \text { ap... } \\
\mathrm{M} \mathrm{a} \ldots \\
\mathrm{M} a \ldots\end{array}$ & $\begin{array}{l}2800-4500 \\
2800-3300 \\
2500-3200 \\
3500-4500 \\
2500-3300\end{array}$ & $\begin{array}{l}3500 \\
3000 \\
3000 \\
4000 \\
3500\end{array}$ & $\begin{array}{r}3500 \\
3000 \\
3200 \\
3100\end{array}$ & \begin{tabular}{r}
3600 \\
\hdashline .3300 \\
3200
\end{tabular} & $\begin{array}{r}3500 \\
3700 \\
3 \ldots \\
3 \ldots \ldots\end{array}$ & $\cdots$ \\
\hline $\begin{array}{l}\boldsymbol{\beta} \text { Pegasl................ } \\
\text { Sun } . . . \ldots \ldots \ldots \ldots \ldots \ldots\end{array}$ & $\begin{array}{l}\mathrm{Mb} \\
\mathrm{Go}\end{array}$ & $\begin{array}{r}2500-3200 \\
\ldots \ldots \ldots \ldots \ldots\end{array}$ & $\begin{array}{r}3000 \\
a 5800-6200\end{array}$ & 2800 & an. & 5320 & \\
\hline
\end{tabular}

$a$ Recalculated from Abbot and Fowle, Jour. Opt. Soc. Am., 5, p. 272; 1921.

In Table 8 are assembled various determinations of the effective stellar temperatures by Nordmann, ${ }^{27}$ and by Nordmann and Le Morvan ${ }^{28}$ also determinations by Wilsing, Scheiner, and Münch, ${ }^{29}$ and calculated values by $\mathrm{Saha}^{30}$ on the basis of ionization theory.

The various methods used to obtain stellar temperatures give different results. For example, Plaskett (see footnote 20 ) obtained an effective temperature of $6800^{\circ} \mathrm{K}$ for $\gamma$ Cassiopeiae (class Bop) by considering the continuous spectrum, and $10600^{\circ} \mathrm{K}$ by considering the bright line spectrum of hydrogen and Bohr's theory of the energy and frequency required to ionize the hydrogen atom. In view of the fact that his continuous spectrum measure-

\footnotetext{
27 Nordmann, C. R., 149, p. 1038; 1909.

${ }_{23}$ Nordmann and Le Morvan, C. R., 173, p. 72; 1921.

${ }^{29}$ Wilsing, Scheiner, and Münch, Publ. Astrophys. Obs., Potsdam, 24, No. 74; 1920.

30 Saha, Proc. Roy. Soc. London (A), 99, p. I35; 1921.
} 
ments terminated at $0.42 \mu$, where also is the maximum spectral energy, it is possible that the higher temperature, estimated on the basis of ionization theory, is the more nearly correct.

Wilsing, Scheiner, and Münch ${ }^{{ }^{2}}$ also obtained a temperature of $6800^{\circ} \mathrm{K}$ for $\gamma$ Cassiopeiae. Their temperature measurements for various stars of class B vary from 7000 to $15000^{\circ} \mathrm{K}$; class A, vary from 8000 to $\mathrm{I} 2000^{\circ} \mathrm{K}$; class $\mathrm{F}$, vary from 5000 to $7000^{\circ}$ $\mathrm{K}$; class $\mathrm{G}$, from 4000 to $5000^{\circ} \mathrm{K}$; and class $\mathrm{M}, 3000$ to $3500^{\circ} \mathrm{K}$.

While it is to be expected that the various methods used must give different results, it is extremely interesting to find a rather close agreement in the estimated temperature as shown in Table 8. The agreement is especially close for stars of classes $G, K$, and $M$; that is, stars having a low temperature.

In conclusion, it may be added that, owing to the nature of the spectral energy distribution of stars at low temperatures as a result of atmospheric absorption, the observed maximum emission is no doubt shifted farther toward the short wave lengths than is the true maximum. Hence, the temperatures may be several hundred degrees lower than here recorded. Similarly, for the B and $\mathrm{A}$ classes of stars, which have their maximum emission in the ultra-violet, the temperatures may be considerably higher than here recorded owing to atmospheric absorption, which shifts the observed (ultra-violet) maximum emission farther toward the visible spectrum than is the true maximum, but which has little effect, relatively, on the infra-red spectral radiation component.

Most of the stars measured are no doubt giants, of which Russel1 ${ }^{31}$ says: "The mean densities of the giant stars diminish rapdly with increasing redness, from one-tenth that of the Sun for class A to less than one twenty-thousandth that of the sun for class M." To those given to speculation concerning the nature of stellar radiation and temperatures it no doubt is of interest to find that the observed radiometric data seem conclusive in showing that the early type (class M) stars are losing heat by radiation three to four times as fast as the more dense but hotter late type (class B, A) stars. The least dense, class $M$, stars must therefore be losing heat by radiation, in which conduction can not contribute very materially in maintaining the surface at a given temperature. This is an interesting subject which should be given further attention.

In the dense stars the shape of the spectral energy curve, and hence our inferences of the effective temperature, is determined by

31 Russell, Pop. Astron., 22, Nos. 5 and 6; 1914. 
the spectral emissivity of the surface, while in the less dense stars the radiation emanates from great depths. Hence, as a matter of caution, it seems well to point out that the present meager data can not safely be used in considering the giant and the dwarf stars of the same class.

\section{SUMMARY}

The object of the present investigation was: (I) To test new stellar thermocouples, (2) to verify previous measurements of stellar radiation, (3) to measure the radiation intensities of bright stars in the region of o hrs. to I 2 hrs., of right ascension, not previously measured, and (4) to determine the feasibility of the method of obtaining the spectral energy distribution of stars by means of transmission screens which, either singly or in combination, are placed in front of the vacuum thermocouple.

By means of vacuum thermocouples measurements were made on the total radiation intensities of $\mathrm{I}_{3}$ bright stars not observed in I9I4, thus completing the survey of the whole sky. A total of 30 celestial objects were measured, including Venus and Mars.

By means of a series of transmission screens (of yellow and red glass, of water, and of a thick plate of quartz) wide spectral regions were isolated and the radiation intensities in the spectrum from $0.3 \mu$ to $0.43 \mu, 0.43 \mu$ to $0.6 \mu, 0.6 \mu$ to I. $4 \mu$, I. $4 \mu$ to $4 . \mathrm{I} \mu$, and 4. I $\mu$ to Io $\mu$ were determined. In this manner the distribution of energy in the spectra of 16 stars was determined, thus obtaining for the first time an insight into the radiation intensities in the complete spectrum of a star.

By means of these transmission screens it was found that in the $\mathrm{B}$ and $\mathrm{A}$ class stars, the maximum radiation intensity lies in the ultra-violet ( $0.3 \mu$ to $0.4 \mu$ ), while in the cooler, $\mathrm{K}$ and $\mathrm{M}$ class, stars the maximum emission lies at $0.7 \mu$ to $0.9 \mu$ in the infra-red. In the case of single stars, at all temperatures, the spectral energy distribution is selective as compared with a black body.

A calculation is made of the spectral component radiations of a black body at various temperatures, using the spectral transmission data on these screens. From a comparison of the observed and the calculated spectral radiation components it appears that the black body temperature (that is, the temperature which a black body would have to attain in order to emit a similar relative spectral energy distribution) varies from $3000^{\circ} \mathrm{C}$ for red, class $\mathrm{M}$, through $6000^{\circ} \mathrm{K}$ for the yellow, solar-type stars, to $10000^{\circ} \mathrm{K}$ or perhaps even higher for blue, class $B$, stars. Owing to selective 
emission the true temperatures are higher than these values for black body radiation.

The observing station being much higher than previously used ( $7300 \mathrm{ft}$. as compared with $4000 \mathrm{ft}$.), the atmospheric scattering of light was greatly reduced, and consequently the transmissions in the violet are somewhat higher than previously observed when the water cell was interposed. However, all the data verify previous-measurements, showing that red stars emit three to four times as much total radiation as blue stars of the same visual magnitude. Moreover, observations made on the same night (same weather conditions) are consistent in showing small gradations in the infra-red radiation component, corresponding with the small gradations (say, $\mathrm{B}_{2}$ and $\mathrm{B} 8$ ) in spectral classes.

For binary stars having companions of low luminosity the water-cell transmissions are low, indicating that the companion stars emit considerable infra-red radiation.

The measurements made with the water cell show that, in blue and yellow stars, practically all the energy lies in that part of the spectrum to which the photographic plate is sensitive. Hence, since the effect on the photographic plate is cumulative, and the time for exposure is relatively unlimited, the spectral energy distribution of many faint stars can be mapped, which will not be possible by any other methods known to us at the present day.

Among the subsidiary investigations made with a view to the improvement of stellar radiometers this paper gives data on the radiation sensitivity of thermocouples of alloys of gold-palladium, platinum-rhodium, bismuth-tin, bismuth-antimony, and also of pure bismuth.

Washington, December 16, I92I. 